\title{
Geographic Distribution and rDNA-ITS Region Sequence Diversity of Waitea circinata var. circinata Isolated from Annual Bluegrass in the United States
}

\author{
Chi-Min Chen and Karla A. de la Cerda, Department of Plant Pathology, University of California, Riverside \\ 92521; John E. Kaminski, Department of Plant Science, University of Connecticut, Storrs 06269; and Greg W. \\ Douhan and Francis P. Wong, Department of Plant Pathology, University of California, Riverside 92521
}

\begin{abstract}
Chen, C.-M., de la Cerda, K. A., Kaminski, J. E., Douhan, G. W., and Wong, F. P. 2009. Geographic distribution and rDNA-ITS region sequence diversity of Waitea circinata var. circinata isolated from annual bluegrass in the United States. Plant Dis. 93:906-911.

Waitea circinata var. circinata is the causal agent of brown ring patch, an emergent disease of turfgrass in the United States. Forty-two isolates from annual bluegrass were obtained from California, Connecticut, Idaho, Illinois, Massachusetts, New York, Ohio, Oregon, and Rhode Island. Almost all isolates produced white to orange sclerotia (bulbils), 2 to $5 \mathrm{~mm}$ in size, that turned dark brown after 21 days on $1 / 4$-strength potato dextrose agar. The ribosomal DNA internal transcribed spacer regions and 5.8S region (ITS) were analyzed by restriction fragment length polymorphism (RFLP) analysis using $M s p I$ and sequencing to attempt identification of the isolates. Some isolates were heterozygous at the $M s p I$ restriction site, results not found in previous reports using the RFLP technique for identification. Four additional nucleotide positions were found to be variable within ITS based on sequence analysis, including two indels and two additional heterozygous positions. A total of 17 ITS haplotypes were found, and there was no obvious relationship between ITS haplotype and the geographic distribution of the isolates. Results of this work indicate that $W$. circinata var. circinata is present in multiple states and provide an initial understanding of the diversity of the pathogen in the United States.
\end{abstract}

Waitea circinata var. circinata has recently been described as the causal agent of brown ring patch in Japan on creeping bentgrass (Agrostis stolonifera L.) (21), and in the United States on annual bluegrass (Poa annua L.) and rough bluegrass (Poa trivialis L.) $(3,5)$. W. circinata var. circinata has a Rhizoctonia anamorph, and is related to $R$. oryzae Ryker \& Gooch (Waitea circinata var. oryzae) and $R$. zeae Voorhees (Waitea circinata var. zeae) $(8,10)$.

In the United States, brown ring patch was first confirmed as a disease in western Washington state in 2003 and recently characterized from annual bluegrass putting greens in the western United States (California, Nevada, and Washington) (5).

Corresponding author: F. P. Wong

E-mail: frank.wong@ucr.edu

The first two authors are considered co-first authors who contributed equally to this work.

Current address of J. E. Kaminski: Department of Crop and Soil Sciences, The Pennsylvania State University, State College, PA 16802.

* The $\boldsymbol{e}$-Xtra logo stands for "electronic extra" and indicates that Figure 1 appears in color in the online edition.

Accepted for publication 29 April 2009

doi:10.1094/PDIS-93-9-0906

(c) 2009 The American Phytopathological Society
It was recognized as a new disease and commonly referred to as "Waitea patch" until it was realized that the same pathogen was responsible for the disease on annual bluegrass in the United States and creeping bentgrass in Japan $(5,21)$.

Symptoms on annual bluegrass as described by de la Cerda et al. (5) include thin yellow rings or semicircles, several centimeters to one meter in diameter, that can turn brown or necrotic and often have a sunken appearance. Symptoms are typically observed at a range of 15 to $35^{\circ} \mathrm{C}$ maximum daytime air temperature. $W$. circinata var. circinata appears to frequently colonize the foliage, crowns, upper roots, and thatch in affected areas. This appears to make control difficult in some cases as multiple fungicide applications are often needed to eradicate the pathogen from the crowns, upper roots, and thatch for complete control. To complicate matters, the disease is superficially similar to other Rhizoctonia diseases such as leaf and sheath spot ( $R$. zeae and $R$. oryzae) or yellow patch ( $R$. cerealis van der Hoeven) that are reported to occur most frequently at high $\left(>28^{\circ} \mathrm{C}\right)$ and low temperatures $\left(<24^{\circ} \mathrm{C}\right)$, respectively $(4,17)$.

In the spring and summer of 2006, yellow rings on annual bluegrass putting greens were reported from more than 50 California golf courses and multiple locations in the Midwest and northeastern United States (K. Dannenberger, M. Boehm, J. Rimmelspach, D. Settle, and J.
Kaminiski, personal communication). These areas include golf course putting greens from Ohio, Illinois, Indiana, Pennsylvania, Connecticut, New York, Massachusetts, Maine, and Rhode Island. In these cases, a Rhizoctonia-like fungus was recovered from symptomatic turf, but it was not clear which species was present.

The objectives of this study were to (i) confirm the presence of $W$. circinata var. circinata as a pathogen of annual bluegrass in these diverse locations in the United States using morphological methods, restriction fragment length polymorphism (RFLP), and sequence analysis of the intergenic spacer (ITS) region, and (ii) assess the diversity of the pathogen ITS region. With regard to the latter objective, identification of a species by ITS region sequence is a useful tool, but there are limited numbers of W. circinata var. circinata isolates that have been characterized $(5,21)$. Assessing the ITS region diversity from a larger number of isolates has implications for improving ITS-based identification methods and would also provide a preliminary indication of intraspecies diversity and the pathogen population biology. For example, no ITS diversity may indicate a recent introduction and spread of this pathogen, whereas variability within this region may indicate that this species was previously present and that other factors such as management practices or environmental changes were responsible for the apparent increase of this "new" disease.

\section{MATERIALS AND METHODS}

Isolate collection and maintenance. Most isolates were collected from diseased $P$. апnиa in 2006, but two isolates collected in 2005 and 2007 were included in this study. A list of isolates used in this study and their geographic origin is shown in Table 1. For isolates collected in the western United States, a single symptomatic leaf blade was placed on 1/4-strength potato dextrose agar in $100-\mathrm{mm}$ petri plates (1/4-PDA; $4.95 \mathrm{~g}$ PDA, $5.63 \mathrm{~g}$ granulated agar [Fisher Scientific, Pittsburgh, $\mathrm{PA}]$ per $500 \mathrm{ml}$ of deionized water $\left[\mathrm{dH}_{2} \mathrm{O}\right]$ ) and incubated at room temperature. After 24 to $48 \mathrm{~h}$, developing colonies on the plates were examined; isolates were identified as Rhizoctonia spp. by the diagnostic 90-degree branching of developing mycelia and colony appearance (18). Each isolate was obtained by transferring a 1- to 2- 
mm hyphal tip to a new 1/4-PDA plate with the aid of a dissecting needle and stereomicroscope. For all other isolates, infected plants were placed onto PDA and emergent hyphae subcultured onto new PDA 24 to $48 \mathrm{~h}$ later. These isolates were subsequently shipped to the Wong lab and hyphal tipped as described above. Unless otherwise noted, isolates were maintained in an incubator at $28^{\circ} \mathrm{C}$ without supplemental light and transferred to new 1/4-PDA every 21 days for the duration of the study.

Morphological characterization. A 5$\mathrm{mm}$ plug of each isolate was transferred to 1/4-PDA and full-strength PDA (19.5 g PDA

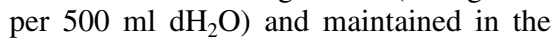
dark at $28^{\circ} \mathrm{C}$. Identification of isolates was based on the width of several vegetative hyphae from 1-week-old cultures, as measured with an optical micrometer (Leica 12.5MZ, Leica Microsystems Inc., Bannockburn, IL), and diagnostic sclerotial (bulbil) and colony morphology from 21-day-old cultures as described by previous studies $(1,5,18,21)$. Morphological characterization was performed three times for each isolate.

DNA extraction and PCR amplification of ITS sequences. DNA extraction and ITS sequence amplification were performed based on methodologies developed by de la Cerda et al. (5). Briefly, for each isolate, DNA was obtained from approximately $10 \mathrm{mg}$ of mycelia scraped from cultures grown on PDA at $28^{\circ} \mathrm{C}$ for 7 days. The PureGene DNA extraction kit (Gentra Systems, Minneapolis, MN) was used for DNA extraction following the manufacturer's instructions. Five microliters of each extraction was separated on a $1.5 \%$ agaroseTBE gel by electrophoresis and stained with SYBR Green I nucleic acid stain (Molecular Probes, Eugene, OR) to estimate quantity and quality of DNA prior to PCR.

Amplification of an approximate 650-bp portion of the rDNA-ITS region was performed using ITS1F (5' CTTGGTCAT TTAGAGGAAGTAA $\left.3^{\prime}\right)$ (6) and ITS4 (5' TCCTCCGCTTATTGATATGC 3') (23). For each isolate, approximately $100 \mathrm{ng}$ of DNA was used for PCR in a $20-\mu l$ reaction volume with a final concentration of 0.2 $\mathrm{mM}$ each dNTP (Invitrogen, Carlsbad, CA), $0.375 \mu \mathrm{M}$ of each oligonucleotide primer, 1× PCR buffer (Invitrogen), 2.5 $\mathrm{mM} \mathrm{MgCl}_{2}$, and 0.5 units of Taq polymerase (Invitrogen). Amplification was performed in a PTC-200 thermocycler (MJ Research, Waltham, MA) using one cycle of $94^{\circ} \mathrm{C}$ for $3 \mathrm{~min}$, followed by 30 cycles of $95^{\circ} \mathrm{C}$ for $30 \mathrm{~s}, 55^{\circ} \mathrm{C}$ for $30 \mathrm{~s}$, and $72^{\circ} \mathrm{C}$ for $1 \mathrm{~min}$. PCR products were examined by electrophoresis with $5 \mu \mathrm{l}$ of each PCR products in $1.5 \%$ agarose-TBE gel to determine the success of amplification for each reaction. Products were stored at $-20^{\circ} \mathrm{C}$ for further restriction enzyme digestion and sequencing.

Restriction enzyme digestion analysis of amplified ITS-sequences. As reported by Toda et al. (21), RFLP analysis of the ITS region with HapII could differentiate W. circinata var. circinata from W. circinata var. oryzae and W. circinata var. zeae. This procedure was used with the intent of rapidly screening and identifying the isolates as different $W$. circinata varieties. One microgram of the amplified rDNAITS region was digested with 10 units of MspI (New England Biolabs, Ipswich, MA), an isoschizomer of HapII. Reactions were incubated for at least $1 \mathrm{~h}$ at $37^{\circ} \mathrm{C}$, and the products were separated and visualized by gel electrophoresis in $2 \%$ agarose-TBE gels.

ITS sequencing and cloning. ITS regions from the isolates were amplified as described above, and sequencing in both directions was performed at the Core Instrumentation Facility (CIF) of the University of California's (UC) Institute of Integrative Genome Biology at UC Riverside. The sequencing reactions failed for some isolates (discussed in the results section), and it was suspected that this was due to indels. Therefore, these ITS PCR products were cloned using the TOPO TA sequenc-

Table 1. Isolates used in this study

\begin{tabular}{|c|c|c|c|c|}
\hline Isolate name & Location & Date collected & Source & $\begin{array}{l}\text { GenBank } \\
\text { accession no. }\end{array}$ \\
\hline AGCCSJ-2.1 & San Jose, CA & $2006 / 7 / 7$ & F. P. Wong & FJ755849 \\
\hline AGTC-4 & Hayden Lake, ID & $2007 / 7 / 5$ & H. C. Wetzel & FJ755890 \\
\hline AVCCPL-0.1 & Placentia, CA & $2006 / 4 / 27$ & F. P. Wong & FJ755850 \\
\hline CCTRTR-1.1 & Troy, NY & $2006 / 7 / 17$ & J. E. Kaminski & FJ755851 \\
\hline CCTRTR-1.2 & Troy, NY & $2006 / 7 / 17$ & F. P. Wong & FJ755852 \\
\hline CDCGTC-9.2 & Trabuco Canyon, CA & $2006 / 7 / 7$ & F. P. Wong & FJ755853 \\
\hline CЕССРО-0.1 & Portland, OR & $2006 / 7 / 7$ & F. P. Wong & FJ755854 \\
\hline CHGCSJ-0.1 & San Jose, CA & $2006 / 7 / 7$ & F. P. Wong & FJ755855 \\
\hline CWCCPL-5.1 & Pleasanton, CA & $2006 / 7 / 7$ & F. P. Wong & FJ755856 \\
\hline DCGCSL-0.1 & San Luis Obispo, CA & $2006 / 6 / 22$ & F. P. Wong & FJ755857 \\
\hline ECGCES-0.1 & Escondido, CA & $2006 / 5 / 29$ & F. P. Wong & FJ755858 \\
\hline FVGCAU-0.1 & Aurora, IL & $2006 / 7 / 19$ & D. M. Settle & FJ755859 \\
\hline GMGCGR-13.1 & Graegle, CA & $2006 / 7 / 7$ & F. P. Wong & FJ755860 \\
\hline HVGCCO-0.1 & Corona, CA & $2006 / 5 / 29$ & F. P. Wong & FJ755861 \\
\hline LACCLA-1.1 & Los Angeles, CA & $2006 / 3 / 1$ & F. P. Wong & FJ755862 \\
\hline LEGCLE-0.1 & Lexington, MA & $2006 / 7 / 17$ & J. E. Kaminski & FJ755863 \\
\hline LRCCLR-18.2 & Thousand Oaks, CA & 2005/12/1 & F. P. Wong & FJ755864 \\
\hline MECCWS-11.1 & Woodside, CA & $2006 / 4 / 27$ & F. P. Wong & FJ755865 \\
\hline MLGCOB- 0.1 & Oak Brook, IL & $2006 / 7 / 19$ & D. M. Settle & FJ755866 \\
\hline MPCCPB-12S.1 & Pebble Beach, CA & $2006 / 5 / 22$ & F. P. Wong & FJ755867 \\
\hline NLCCNL-0.1 & New London, CT & $2006 / 7 / 17$ & J. E. Kaminski & FJ755889 \\
\hline NSCCGL-0.1 & Glenview, IL & $2006 / 7 / 19$ & D. M. Settle & FJ755868 \\
\hline NWCCNO-0.1 & Norwich, CT & $2006 / 7 / 17$ & J. E. Kaminski & FJ755869 \\
\hline ONCCST-0.1 & Stratford, CT & $2006 / 7 / 18$ & J. E. Kaminski & FJ755870 \\
\hline PPGCAU-0.1 & Aurora, IL & $2006 / 7 / 19$ & D. M. Settle & FJ755871 \\
\hline РТCСМА- 0.1 & Marysville, CA & $2006 / 7 / 7$ & F. P. Wong & FJ755872 \\
\hline RHCCTE-3.1 & Temecula, CA & $2006 / 3 / 1$ & F. P. Wong & FJ755873 \\
\hline RHCCTE-15.2 & Temecula, CA & $2006 / 3 / 1$ & F. P. Wong & FJ755874 \\
\hline RMCCHO-0.1 & Hollister, CA & $2006 / 7 / 7$ & F. P. Wong & FJ755875 \\
\hline SCCCHB-18.1 & Huntington Beach, CA & $2006 / 7 / 7$ & F. P. Wong & FJ755876 \\
\hline SDGCSD-0.1 & San Dimas, CA & $2006 / 5 / 22$ & F. P. Wong & FJ755877 \\
\hline SICCNA-0.1 & Napa, CA & $2006 / 6 / 1$ & F. P. Wong & FJ755878 \\
\hline TECCMA- 0.1 & Marblehead, MA & $2006 / 7 / 19$ & J. E. Kaminski & FJ755879 \\
\hline TPCGLJ-18S.1 & La Jolla, CA & $2006 / 6 / 5$ & F. P. Wong & FJ755880 \\
\hline TPCGLJ-18S.2 & La Jolla, CA & $2006 / 6 / 5$ & F. P. Wong & FJ755881 \\
\hline TVCCSJ-0.1 & San Jose, CA & $2006 / 5 / 29$ & F. P. Wong & FJ755882 \\
\hline WACCRU-0.1 & Rumford, RI & $2006 / 7 / 20$ & J. E. Kaminski & FJ755883 \\
\hline WRCCAL-0.1 & Albany, NY & $2006 / 7 / 17$ & J. E. Kaminski & FJ755884 \\
\hline WSCCLA-5.1 & Los Angeles, CA & $2006 / 6 / 15$ & F. P. Wong & FJ755885 \\
\hline WTCCWT-0.1 & Watertown, CT & $2006 / 7 / 17$ & J. E. Kaminski & FJ755886 \\
\hline YOGTYO-0.1 & York, ME & $2006 / 7 / 21$ & J. E. Kaminski & FJ755887 \\
\hline $06-487$ & Columbus, $\mathrm{OH}$ & $2006 / 6 / 1$ & J. Rimelspach & FJ755888 \\
\hline
\end{tabular}

ing cloning system (Invitrogen) as described by the manufacturer. Positive clones were transferred to $100 \mu \mathrm{l}$ of LuriaBertani (LB) broth amended with 100 $\mu \mathrm{g} / \mathrm{ml}$ ampicillin (Sigma Chemical Co., St. Louis, MO) in sterile 96-well microtiter plates and incubated overnight at $37^{\circ} \mathrm{C}$. Five clones from each isolate were reamplified using ITS1F and ITS4, and sequencing was performed as described above. The sequences were edited using Sequencher (version 4.6, Gene Codes Corporation, Ann Arbor, MI), Clustal X (version 1.81) (20) was used for alignment, and MacClade version 4 (11) was used for visual editing.

\section{RESULTS}

Morphological identification of isolates. All isolates examined in this study were morphologically similar to $W$. circinata var. circinata isolates as previously described by Toda et al. (21) and de la Cerda et al. (5) based on hyphal width and mycelial and sclerotial morphology. The production of a thick buff colored mycelial mat on PDA often obscured the production 


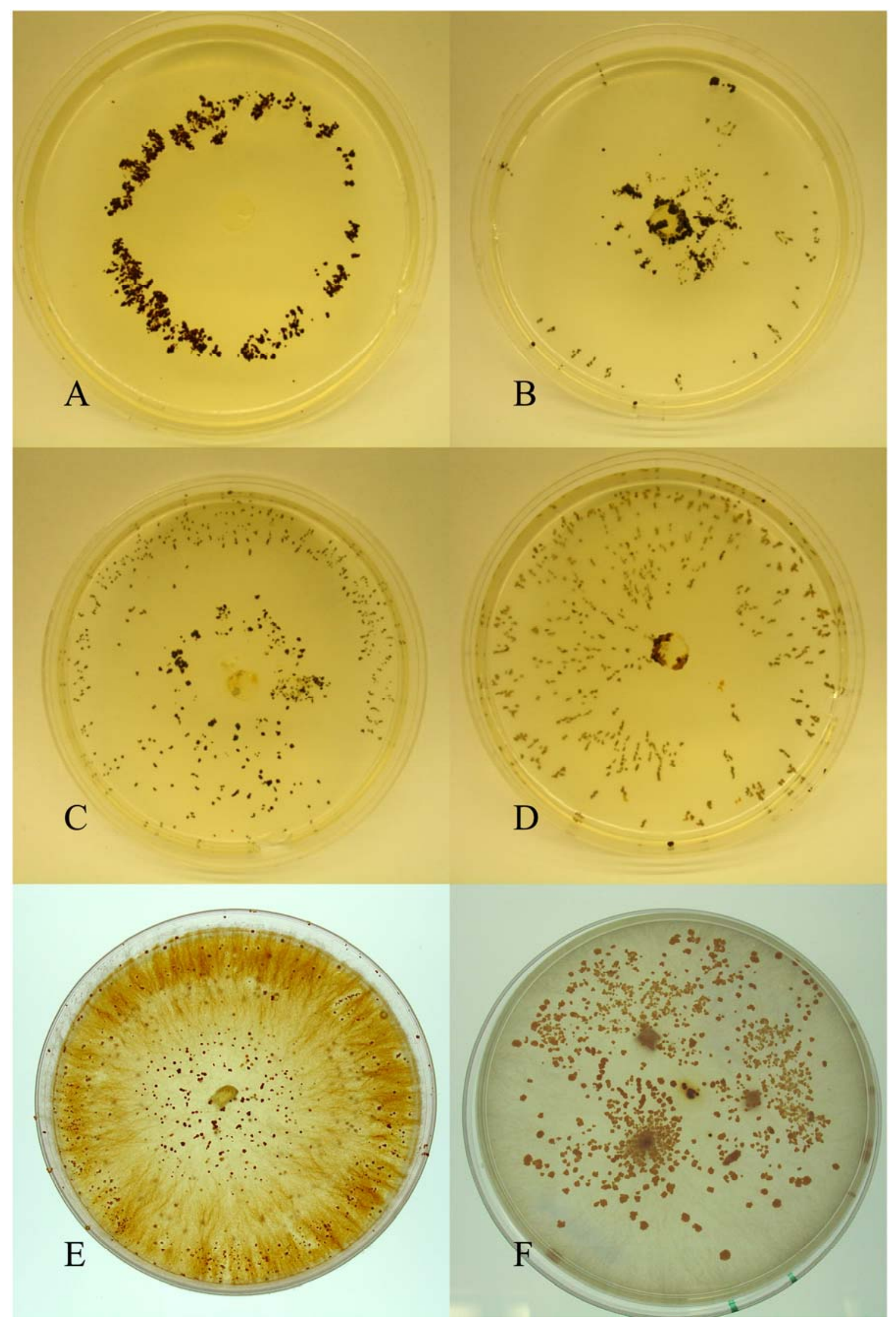

Fig. 1. Morphology of Waitea circinata var. circinata isolates on 1/4-strength potato dextrose agar after 21 days incubation. Variations in morphology include A, dark brown sclerotia on the agar surface, $\mathbf{B}$ and $\mathbf{C}$, mixture of large and small dark brown sclerotia on top of and embedded in the agar, and $\mathbf{D}$, mixture of orange, whitish, and dark brown sclerotia. Morphology of isolates can vary, but these are clearly distinguishable from other W. circinata varieties such as $\mathbf{E}$, Rhizoctonia zeae (W. circinata var. zeae), which produces reddish sclerotia, and $\mathbf{F}$, Rhizoctonia oryzae (W. circinata var. oryzae), which produces pink to salmon sclerotia after 21 days incubation on 1/4-strength potato dextrose agar. 
and morphology of the diagnostic sclerotia of the isolates, thus the morphological characteristics on 1/4-PDA were more uniform for identification purposes. All isolates produced thin buff colored mycelia on $1 / 4-P D A$, but the best diagnostic feature was the production of irregular 2- to 5-mm white to orange sclerotia within 7 to 14 days that turned dark brown by 21 days of incubation. Two isolates (PTCCMA-0.1, NWCCNO-0.1) did not turn dark brown after 21 days, retaining a white to orange color. Some others had a mixture of dark brown, orange, and white sclerotia on the media. For individual isolates, sclerotia were produced on the medium surface, embedded in the medium, or a combination of both. Some isolates often had variation in morphology and the location of sclerotial production (on or in the media) during the three replicated tests, while others were morphologically consistent in all three tests. Although these variations in colony morphology were present on $1 / 4$ -

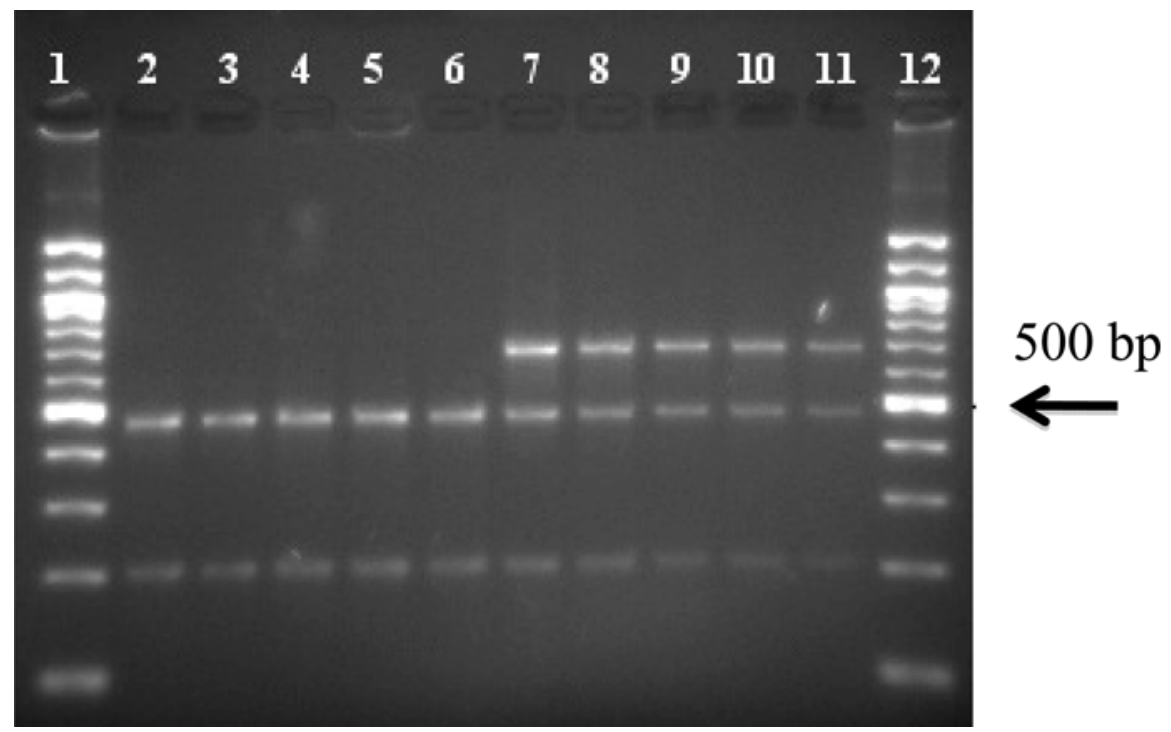

Fig. 2. MspI digestion of amplified ribosomal DNA intergenic spacer (rDNA-ITS) regions from representative isolates ( 1 unit per $100 \mathrm{ng}$ DNA) followed by gel electrophoresis in a $2 \%$ agarose-TBE gel. Lanes 2 to 6 represent isolates that are homozygous at the MspI/HapII restriction site yielding two fragments of sizes $\sim 170$ and $470 \mathrm{bp}$. Lanes 7 to 11 represent isolates that were heterozygous at the $M s p$ I restriction site leading to the production of fragments of sizes $\sim 170$ and 470 bp and uncut polymerase chain reaction product ( $\sim 650 \mathrm{bp})$. Lanes 1 and 12 are a 100-bp ladder

PDA, the presence of dark brown or orange sclerotia was always associated with W. circinata var. circinata isolates, and these features were clearly distinct from the two other $W$. circinata varieties, $R$. oryzae and $R$. zeae (Fig. 1).

RFLP and sequence analysis. Initial RFLP analyses showed that digestion of the amplified ITS-regions with MspI produced the diagnostic 470- and 170-bp bands when visualized by gel electrophoresis (Fig. 2). However, six isolates analyzed in this manner produced bands of 650 (uncut), 470, and 170 bp (Fig. 2). Sequencing analysis indicated that these isolates were heterozygous at the $M s p \mathrm{I} /$ HapII restriction site (nucleotide position 183 ), and therefore presumably only part of the DNA was being digested. In total, five nucleotide positions were found to be variable within the ITS; two indels and three heterozygous positions (including position 183 mentioned above). The two single-base-pair indels within the poly A/T stretches were first putatively identified from failed sequencing reads. In these cases, sequence reads of the amplified ITS regions appeared normal until nucleotide positions 235 and or 438 ; sequencing reads past these points were unreadable due to the frame shift in the sequencing read caused by the indels. The presence of variable poly $\mathrm{A} / \mathrm{T}$ regions at these locations was confirmed through cloning and sequencing multiple clones (Table 2). Seventeen unique ITS haplotypes were found, and most of the isolates belonged to haplotype 3 (Table 2). No obvious relationships between isolate geographical origin and haplotype were observed.

Table 2. Heterozygous and indel positions present in the ITS1F/ITS4 amplified sequence of the ribosomal DNA intergenic transcribed spacer (rDNA-ITS) region for selected isolates of Waitea circinata var. circinata

\begin{tabular}{|c|c|c|c|c|c|c|c|c|}
\hline \multirow[b]{2}{*}{ ITS haplotype } & \multicolumn{5}{|c|}{ Nucleotide position $(\mathbf{b p})^{y}$} & \multirow[b]{2}{*}{ Isolate } & \multirow[b]{2}{*}{ Occurrence } & \multirow[b]{2}{*}{ Origin } \\
\hline & 149 & $183^{\mathrm{z}}$ & 235 & 438 & 439 & & & \\
\hline 1 & $\mathrm{C}$ & $\mathrm{C}$ & $\mathrm{T} /-$ & $\mathrm{T} /-$ & A & SICCNA-0.1 & 1 & CA \\
\hline 2 & $\mathrm{C}$ & $\mathrm{C}$ & $\mathrm{T}$ & $\mathrm{T} /-$ & $\mathrm{A} / \mathrm{G}$ & CWCCPL-5.1 & 1 & CA \\
\hline 3 & $\mathrm{C}$ & $\mathrm{C}$ & $\mathrm{T}$ & - & G & $\begin{array}{l}\text { AGCCSJ-2.1, AGTC-4, AVCCPL-0.1, CCTRTR-1.2, } \\
\text { CDCGTC-9.2, CHGCSJ-0.1, DCGCSL-0.1, ECGCES- } \\
\text { 0.1, HVGCCO-0.1, MLGCOB-0.1, MPCCPB-12S.1, } \\
\text { RHCCTE-15.2, SDGCSD-0.1, TECCMA-0.1, } \\
\text { TPGCLJ-18S.2, WSCCLA-5.1, WTCCWT-0.1, } \\
\text { WRCCAL-0.1, 06-487 }\end{array}$ & 19 & $\begin{array}{l}\text { CA, CT, ID, IL, } \\
\text { NY, OH, MA }\end{array}$ \\
\hline 4 & $\mathrm{C}$ & $\mathrm{C}$ & $\mathrm{T} /-$ & - & G & GMGCGR-13.1 & 1 & $\mathrm{CA}$ \\
\hline 5 & $\mathrm{C}$ & $\mathrm{C}$ & $\mathrm{T} /-$ & - & $\mathrm{A} / \mathrm{G}$ & LACCLA-1.1, TPGCLJ-18S.1 & 2 & $\mathrm{CA}$ \\
\hline 6 & $\mathrm{C}$ & $\mathrm{T} / \mathrm{C}$ & $\mathrm{T}$ & $\mathrm{T} /-$ & $\mathrm{A} / \mathrm{G}$ & PTCCMA-0.1, RHCCTE-3.1 & 2 & $\mathrm{CA}$ \\
\hline 7 & $\mathrm{C}$ & $\mathrm{T} / \mathrm{C}$ & $\mathrm{T} /-$ & - & $\mathrm{G}$ & ONCCST-0.1 & 1 & $\mathrm{CT}$ \\
\hline 8 & $\mathrm{C}$ & $\mathrm{T} / \mathrm{C}$ & $\mathrm{T}$ & - & G & YOGTYO-0.1, CECCPO-0.1, CCTRTR-1.1 & 3 & ME, OR, NY \\
\hline 9 & G & $\mathrm{C}$ & T/- & - & A & LEGCLE- 0.1, NWCCNO-0.1 & 2 & MA, CT \\
\hline 10 & G & $\mathrm{C}$ & - & - & $\mathrm{A} / \mathrm{G}$ & FVGCAU-0.1 & 1 & $\mathrm{IL}$ \\
\hline 11 & G & $\mathrm{C}$ & - & - & A & SCCCHB-18.1 & 1 & $\mathrm{CA}$ \\
\hline 12 & $\mathrm{C} / \mathrm{G}$ & $\mathrm{C}$ & $\mathrm{T} /-$ & - & G & NLCCNL-0.1 & 1 & $\mathrm{CT}$ \\
\hline 13 & $\mathrm{C} / \mathrm{G}$ & $\mathrm{C}$ & $\mathrm{T} / \mathrm{-}$ & - & $\mathrm{A} / \mathrm{G}$ & PPGCAU-0.1, RMCCHO-0.1 & 2 & $\mathrm{IL}, \mathrm{CA}$ \\
\hline 14 & $\mathrm{C} / \mathrm{G}$ & $\mathrm{C}$ & $\mathrm{T} /-$ & - & A & WACCRU-0.1 & 1 & RI \\
\hline 15 & $\mathrm{~T} / \mathrm{G}$ & $\mathrm{C}$ & - & - & $\mathrm{A} / \mathrm{G}$ & LRCCLR-18.2 & 1 & $\mathrm{CA}$ \\
\hline 16 & $\mathrm{~T}$ & $\mathrm{C}$ & T/- & - & $\mathrm{A} / \mathrm{G}$ & MECCWS-11.1 & 1 & $\mathrm{CA}$ \\
\hline 17 & $\mathrm{~T}$ & $\mathrm{C}$ & $\mathrm{T} /-$ & - & $\mathrm{G}$ & NSCCGL-0.1, TVCCSJ-0.1 & 2 & $\mathrm{IL}, \mathrm{CA}$ \\
\hline
\end{tabular}

${ }^{y}$ Nucleotide position is relative to the end of the ITS1F priming site. A single nucleotide represents a homozygous position, two nucleotides represent a heterozygous position, and - represents no $\mathrm{T}$ at this position relative to the other sequences since these are poly $\mathrm{T}$ stretches of sequence data. Position 235 consists of 5 or 6 poly T's, and position 438 consists of 8 or 9 poly T's.

${ }^{\mathrm{z}}$ Nucleotide position 183 corresponds to the variable position within the MspI/HapII cutting site (5' CCGG 3'). 


\section{DISCUSSION}

An issue that emerged while performing this work was the taxonomy and name of the brown ring patch pathogen. Currently, only the species Waitea circinata Warcup \& Talbot (22) is recognized, and the use of $W$. circinata varieties to describe the pathogen causing brown ring patch and the teleomorphs of $R$. oryzae and $R$. zeae (8) may be taxonomically invalid at this time. The use of Rhizoctonia circinata varieties circinata, oryzae, and zeae to describe the anamorphs of $W$. circinata, as proposed by Leiner and Carling (10), is lacking a formal taxonomic description according to the International Code of Botanical Nomenclature, and the use of Chrysorhiza zeae as an anamorphic name for W. circi$n a t a$, as proposed by Stalpers and Andersen (19), does not appear to be adequate for distinguishing theses three pathogens from each other. However, it is clear that brown ring patch is caused by a Rhizoctonia species distinct from $R$. oryzae and $R$. zeae $(5,8,10,21)$, and for the time being, the use of $W$. circinata and the variety designation is very practical in the context of describing the pathogen causing brown ring patch and its relationship to other Rhizoctonia species. However, additional work must be performed to resolve the of the scope of the studies presented here.

In this work, we present information on the recent development and emergence of W. circinata var. circinata as a common pathogen of annual bluegrass in the United States. We have shown that $W$. circinata var. circinata is present as a pathogen of annual bluegrass across a wide geographic distribution in the United States and completed a preliminary assessment of genetic diversity within the pathogen based on ITS sequences. This analysis also revealed taxonomy of this group, which is outside

unexpected ITS variability compared to previous studies $(5,21)$, which could potentially impact diagnostic methods used to identify this pathogen.

Previously, W. circinata var. circinata was shown to be a pathogen of annual bluegrass from nine locations in California, Nevada, and Washington in the United States (5) and of rough bluegrass in two locations in California (3). In this work, we show that the pathogen is also present across a wide range of locations including Connecticut, Idaho, Illinois, Massachusetts, New York, Ohio, Oregon, and Rhode Island. A larger sample of California isolates also shows that the pathogen is widely distributed within the state. Additional reports of the disease from locations in the Midwest and eastern United States require further confirmation of the presence of the pathogen, but our data presented here do indicate that $W$. circinata var. circinata is widespread in the United States (Fig. 3).

Data obtained from our disease diagnostic clinic at UC Riverside indicate that $W$. circinata var. circinata is the dominant Rhizoctonia disease of annual bluegrass in California. From 2006 to 2008, more than 90 Rhizoctonia isolates were obtained from California annual bluegrass putting green samples showing symptomatic yellow rings. Only two of these were identified as $R$. zeae (W. circinata var. zeae), none as $R$. oryzae (W. circinata var. oryzae), and two as $R$. cerealis (F. Wong, unpublished data); the rest appeared to be W. circinata var. circinata based solely on morphological characteristics and timing of the disease $\left(15\right.$ to $35^{\circ} \mathrm{C}$ maximum daytime temperatures with the majority of samples arriving during periods of 25 to $30^{\circ} \mathrm{C}$ maximum daytime temperature). Of some $>500$ annual bluegrass putting green

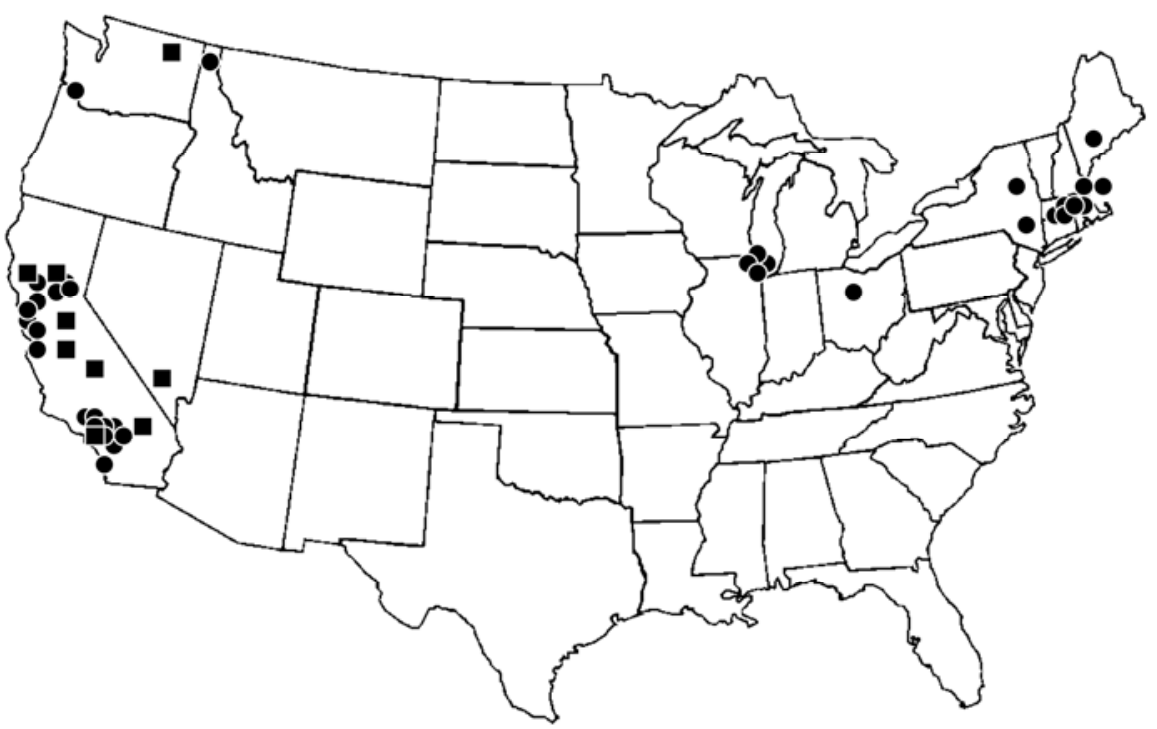

Fig. 3. Geographic distribution of Waitea circinata var. circinata isolates identified in this study. Circles represent the approximate geographic origin of isolates used in this study, while squares represent the origin of previously characterized isolates (5). Outline map generated using Smart Draw (San Diego, CA). samples we examined in the UC Riverside turf disease diagnostic clinic during this period, none were found to be affected by $R$. solani, suggesting that $W$. circinata var. circinata is favored in this semi-arid environment on annual bluegrass putting greens. As discussed by de la Cerda et al. (5), and reinforced by the data presented in this study, it does appear that $W$. circinata var. circinata is a common and widespread pathogen in this geographic area. Other areas where $W$. circinata var. circinata isolates were obtained (the midwestern and northeastern United States) tend to have more diseases caused by other Rhizoctonia species, and it is unclear at this time how frequently brown ring patch occurs in relation to these other Rhizoctonia diseases.

In this study, we found that a majority of W. circinata var. circinata isolates shared common morphological features when grown on $1 / 4$-PDA that can help in the diagnosis of the pathogen from field samples. Variation in sclerotial size, location on and in the media, timing of production in culture, and color were present, but generally the sclerotia of these isolates could be produced submerged in the medium, on the medium surface, or in both in combination, were 2 to $5 \mathrm{~mm}$ in size, and were initially white to orange with most of the sclerotia turning dark brown over time. No correlation was found between morphological variation and ITS haplotype or geographic origin. The development of the sclerotia of $W$. circinata var. circinata is distinct from $W$. circinata var. zeae isolates, which produce smaller sclerotia submerged and embedded in the agar that develop a reddish color over time. However, W. circinata var. circinata may be confused with $W$. circinata var. oryzae, since the latter is often described as having large sclerotia with a salmon color (15), which can be potentially confused with the orangish color of developing (and some older) W. circinata var. circinata sclerotia. A larger study comparing the sclerotial morphology of a range of $W$. circinata isolates would allow us to determine the usefulness of this feature for the clear differentiation of $W$. circinata varieties. For the time being, a combination of morphological characteristics in culture and molecular testing would be recommended for correct identification of $W$. circinata var. circinata from diagnostic samples.

Molecular identification of $W$. circinata var. circinata by sequence analysis of the ITS region appears to be reliable, as the sequences were quite similar to each other and divergent from other Rhizoctonia species as shown in previous studies $(5,21)$. ITS sequence has been shown to be very useful for separating Rhizoctonia species and anastomosis groups and also supports the separation of Waitea spp. from Thanatephorus spp. and Ceratobasidium spp., additional teleomorphic genera with Rhizoctonia anamorphs $(9,16)$. However, 
the presence of indels in the ITS region interfered with direct sequencing of PCR products from some isolates in this study, which has also been determined for other basidiomycetes, including Rhizoctonia species (7). Even when no indels are present, we found a heterozygous position in the diagnostic RFLP site that was not previously reported by de la Cerda et al. (5) and Toda et al. (21) which was most likely due to the limited number of isolates examined in either study. Finding heterozygosity is also not unexpected in a dikaryotic fungus and has also been found in other Rhizoctonia species $(2,14)$. Obviously, any diagnostic tool used to identify a target fungal species is only as robust as the number and diversity of isolates used to screen for such markers. Therefore, the utility of the RFLP analysis based on digestion of ITS with MspI or HapII to differentiate varieties of $W$. circinata merits further examination. Possibly, there are $W$. circinata var. circinata isolates that are completely lacking the restriction enzyme recognition site and isolates of $W$. circinata var. zeae and W. circinata var. oryzae that have it. Only additional studies examining a larger number of $W$. circinata isolates, of all varieties, would elucidate this.

One objective of this study was to use ITS sequences in an initial attempt to assess the overall diversity of the $W$. circinata var. circinata isolates in order to begin to understand the population biology of this apparent "newly emerging" disease. ITS sequence diversity was limited to only five nucleotide positions, but the presence of indels and heterozygosity resulted in a total of 17 unique ITS variants with no obvious relationship between isolate origin and ITS haplotype. This would support the hypothesis that the emergence of the pathogen as a problem is due to changes in turfgrass cultural practices or environmental conditions. This is also supported by preliminary data from amplified fragment length polymorphism (AFLP) analyses showing that genome-wide polymorphisms are common (C. Chen, unpublished data). Moreover, isolates described as $W$. circinata var. circinata were isolated from turf in California in the mid-1980s (8), isolated from soil in Alaska in the mid1990s (10), and reported as a pathogen of rice in California (8), suggesting the wide distribution of this species. Additional comparison of the amplified ITS regions used in this study aided by Blastn comparisons of ITS sequences previously deposited in GenBank also revealed nearly identical sequences associated with isolates identified as $R$. oryzae from wheat in the Pacific Northwest $(12,13)$. Although it is unknown if these are truly the same as our W. circinata var. circinata populations affecting annual bluegrass in the United States, it does suggest that this is a more widespread pathogen of grasses in the United States than previously recognized. Additional studies using AFLP analysis and multilocus sequencing approaches are currently being pursued in order to more robustly test the hypothesis that $W$. circinata var. circinata is not a recently introduced species and to help better characterize the population structure of this pathogen.

Identification of the factors contributing to the development of the disease on turfgrass in response to either changes in management programs for turfgrass or potentially larger issues such as global climate change are of the highest importance. The current challenges with this pathogen are to understand how to best manage this disease on golf course putting greens, with respect to the impact of fungicide applications and cultural controls, and to determine what factors have caused this disease to emerge as a major and widespread problem.

\section{ACKNOWLEDGMENTS}

We thank the California State Golf Course Superintendents of America and its Northern California, Southern California, Hi-Lo Desert, San Diego, and Sierra Nevada Chapters for research funding used to conduct this work. The University of California Agricultural Experiment Station provided additional funding. We thank D. Settle of the Chicago District Golf Association, J. Rimelspach and $\mathrm{M}$. Boehm, and $\mathrm{H}$. Wetzel for their isolates collected from Illinois, Ohio, and Idaho, respectively.

\section{LITERATURE CITED}

1. Burpee, L., and Martin, B. 1992. Biology of Rhizoctonia species associated with turfgrasses. Plant Dis. 76:112-117.

2. Ceresini, P. C., Shew, H. D., Vilgalys, R. J., Gale, L. R., and Cubeta, M. A. 2003. Detecting migrants in populations of Rhizoctonia solani anastomosis group 3 from potato in North Carolina using multilocus genotype probabilities. Phytopathology 93:610-615.

3. Chen, C. M., Douhan, G. W., and Wong, F. P. 2007. First report of Waitea circinata var. circinata causing brown ring patch on Poa trivialis in California. Plant Dis. 91:1687.

4. Couch, H. B. 1995. Diseases of Turfgrass, 3rd ed. Krieger Publishing, Malabar, FL.

5. de la Cerda, K. A., Douhan, G. W., and Wong, F. P. 2007. Discovery and characterization of Waitea circinata var. circinata affecting annual bluegrass from the western United States. Plant Dis. 91:791-797.

6. Gardes, M., and Bruns, T. D. 1993. ITS primers with enhanced specificity for Basidiomycetes - Application to the identification of mycorrhizae and rusts. Mol. Ecol. 2:113-118.

7. Gonzalez, D., Cubeta, M. A., and Vilgalys, R. 2006. Phylogenetic utility of indels within ribosomal DNA and beta-tubulin sequences from fungi in the Rhizoctonia solani species complex. Mol. Phylogenet. Evol. 40:459-470.

8. Gunnell, P. S. 1986. Characterization of the telemorphs of Rhizoctonia oryzae-sativae, Rhizoctonia oryzae, and Rhizoctonia zeae, and the effect of cultural practices on aggregate sheath spot of rice, caused by Rhizoctnia oryzae-sativae. Ph.D. thesis. University of California, Davis

9. Hsiang, T., and Dean, J. D. 2001. DNA sequencing for anastomosis grouping of Rhizoctonia solani isolates from Poa апnиa. Int Turfgrass Soc. Res. J. 9:674-678.

10. Leiner, R. H., and Carling, D. E. 1994. Characterization of Waitea circinata (Rhizoctonia) isolated from agricultural soils in Alaska. Plant Dis. 78:385-388.

11. Maddison, D. R., and Maddison, W. P. 2001. MacClade: Analysis of Phylogeny and Character Evolution. Sinauer Associates, Sunderland, MA.

12. Mazzola, M., Wong, O. T., and Cook, R. J. 1996. Virulence of Rhizoctonia oryzae and $R$. solani AG-8 on wheat and detection of $R$ oryzae in plant tissue by PCR. Phytopathology 86:354-360.

13. Okubara, P. A., Schroeder, K. L., and Paulitz, T. C. 2008. Identification and quantification of Rhizoctonia solani and $R$. oryzae using realtime polymerase chain reaction. Phytopathology 98:837-847.

14. Rosewich, U. L., Pettway, R. E., McDonald, B. A., and Kistler, H. C. 1999. High levels of gene flow and heterozygote excess characterize Rhizoctonia solani AG-1 IA (Thanatephorus cucumeris) from Texas. Fungal Genet. Biol. 28:148-159.

15. Ryker, T. C., and Gooch, F. S. 1938. Rhizoctonia sheath spot of rice. Phytopathology 28:233-246.

16. Sharon, M., Kuninaga, S., Hyakumachi, M., and Sneh, B. 2006. The advancing identification and classification of Rhizoctonia spp. using molecular and biotechnological methods compared with the classical anastomosis grouping. Mycoscience 47:299-316.

17. Smiley, R. W., Dernoeden, P. H., and Clarke, B. B. 2005. Compendium of Turfgrass Diseases, 3rd ed. American Phytopathological Society, St. Paul, MN.

18. Sneh, B., Burpee, L., and Ogoshi, A. 1991. Identification of Rhizoctonia Species. American Phytopathological Society, St. Paul, MN.

19. Stalpers, J. A., and Andersen, T. F. 1996. A synopsis of the taxonomy of teleomorphs connected with Rhizoctonia S. L. Pages 49-63 in: Rhizoctonia Species: Taxonomy, Molecular Biology, Ecology, Pathology and Disease Control. B. Sneh, S. Jabaji-Hare, S. Neate, and G. Dijst, eds. Kluwer Academic Publishers, Dordrecht, Netherlands.

20. Thompson, J. D., Plewniak, F., and Poch, O 1999. A comprehensive comparison of multiple sequence alignment programs. Nucleic Acids Res. 27:2682-2690.

21. Toda, T., Mushika, T., Hayakawa, T., Tanaka, A., Tani, T., and Hyakumachi, M. 2005. Brown ring patch: A new disease on bentgrass caused by Waitea circinata var. circinata. Plant Dis. 89:536-542.

22. Warcup, J. H., and Talbot, P. H. B. 1962. Ecology and identity of mycelia isolated from soil. Trans. Br. Mycol. Soc. 45:495-518.

23. White T. J., Bruns, T., Lee, S., and Taylor, J. 1990. Amplification and direct sequencing of fungal ribosomal RNA genes for phylogenetics. Pages 315-322 in: PCR Protocols: A Guide to Methods and Applications. M. A. Innis, D. H. Gelfand, J. J. Sninsky, and T. J. White eds. Academic Press, San Diego, CA. 